\title{
MODELLING THE IMPACT OF ANTHROPOGENIC MODIFICATIONS TO RIVER CHANNELS ON THE COURSE OF EXTREME FLOODS. CASE STUDY: AUGUST 2002 FLOOD, BLANICE RIVER BASIN, CZECHIA.
}

$\mathrm{J}$. L a n g h a m m e r, J . S i t a ř : Modelling the impact of anthropogenic modifications to river channels on the course of extreme floods. Case study: August 2002 flood, Blanice River basin, Czechia. - Geografie-Sborník CGS, 113, 3, pp. 237-252 (2008). - This paper presents the results of analysis of the impact of anthropogenic modifications to river channels on the course of floods by means of hydraulic modelling. The study is focused on the quantitative analysis of changes of the flow dynamics in the river bed and in the inundation zone due to river network modifications. The one-dimensional hydraulic model HEC-RAS coupled with GIS is used to simulate the effect of the river channel changes on the course of extreme flood. The analysis is made on the example of the extreme flood in August 2002 on the down course of Blanice River in Czechia. The results of the simulations proved that the common anthropogenic modifications of river channel have only a minimum impact on the overall course of extreme floods. At the local level, weirs and unsuitably dimensioned bridges have a negative impact on the course of floods. The simulations also showed a negative impact of extensive complex modifications of the river bed, performed in the lower course of Blanice River in the first half of the 20th century. However, the overall impact of common types of river channel modifications on peak flows and water levels in the culmination is negligible.

KEY WORDS: floods - modelling - hydrological extremes - floodplain - stream modifications.

The presented research was funded by the Joint Research Scheme MSM 0021620831 „Geographical Systems and Risk Processes in Context of Global Changes and European Integration" which is fully appreciated by the authors.

\section{Introduction}

Anthropogenic modifications of river networks and river basins may, according to geographical and hydrometeorological conditions, have significant impacts on the course and consequences of floods. The effects are apparent at the local scale as well as at the river basin scale, and may affect the course as well as magnitude of the event (Gilvear 1999). Anthropogenic modifications which may have the most marked impacts on the passing of the flood wave through the inundation zone include changes of the river bed route, modifications of the watercourse longitudinal profile, changes of transversal profiles, and changes in the nature of land use of the floodplain and the riparian zone (De Roo et al. 2001, Langhammer 2006). 
Intensive changes in the landscape and floodplain, and modifications of streams are manifested by accelerated runoff from the landscape, increases of flow speed in the riverbed, higher steepness of the flood wave, and changes in timing of flood waves from parts of the river basin by decreased transformation and retention capacity of the landscape and alluvial plain, or by resulting increases of peak flow and peak water level values. The manifestations of changes in the landscape mentioned above differ in their effects with varied levels of the flood extremity; moreover, individual factors have a different impact on various spatial levels of assessment as well as depending on the flood event extremity.

Suitable tools to study the impact of such modifications of river bed environments on the course of floods are represented by mathematical models that make it possible to simulate the effect of individual modification types of the river bed on the course of the flood, and to simulate the effects of floodprotection measures. One-dimensional or two-dimensional hydrodynamic models can be used to simulate the hydrological course of the flood depending on the change of external conditions (Bates, de Roo 2000; Horrit, Bates, 2002). One-dimensional models (for example, MIKE 11 and HEC-RAS) make it possible to calculate basic characteristics of the flow and inundation in a given time step. Outputs of these models provide information on the flows, water level heights, and extent of the flood spill. On the contrary, twodimensional models (for example, MIKE 21 and FLO-2D) make it possible to express in substantially greater detail the dynamics of flow within the entire flood range, and thus to express the distribution of flow depths and speeds in individual grid fields into which the flood area is decomposed (Beffa, Connell 2001; Beven 2001; Verwey 2001).

The issue of impact of anthropogenic changes in the river bed on the flood course is evaluated using the model example of the Blanice River basin in Czechia (Fig. 1) for the case corresponding to the extreme flood in August 2002. The intensity of straightening of the Blanice River course in this area is extraordinary - during the past 150 years, the river has been shortened by $38 \%$ between Bavorov and the confluence with the Otava River (Langhammer, Vajskebr 2003). Complex, historic modification of the river bed, including flood protection barriers, does not allow full utilization of the natural retention and transformation potential offered by the flat and up to 2 $\mathrm{km}$ wide floodplain in the area. The riverbed itself is moreover affected by numerous interventions in the longitudinal profile and crossed by numerous communication lines. Some bridges, roads, and railways are not dimensioned sufficiently and this, according to consequence analyses results of the 2002 flood, leads to the increased intensity and frequency of erosion-accumulation as well as destruction manifestations of floods (Hartvich et al. 2007).

This paper presents analysis results of the impacts of basic water management modification types of watercourse beds on the course of extreme floods as calculated using a mathematical hydraulic model. The impacts of weirs, bridges, railway embankments crossing the floodplain, and flood protection dikes are studied by means of hydraulic modelling. The onedimensional hydraulic model HEC-RAS was used for quantitative assessment of the impact of the interventions in the bed and floodplain geometry. 


\section{Materials and Methods}

\subsection{Study Area}

The watercourse of the Blanice River in South Bohemia, Czechia, was chosen as the model basin. The specific area used for modelling was the lower part of the stream between Bavorov and the mouth profile at the confluence point with the Otava River (Fig. 1).

The Blanice River basin is situated in the foothills of the Sumava Mountains, and its relief and natural conditions, as well as the intensity of anthropogenic utilization, are variable. The spring area of the river basin

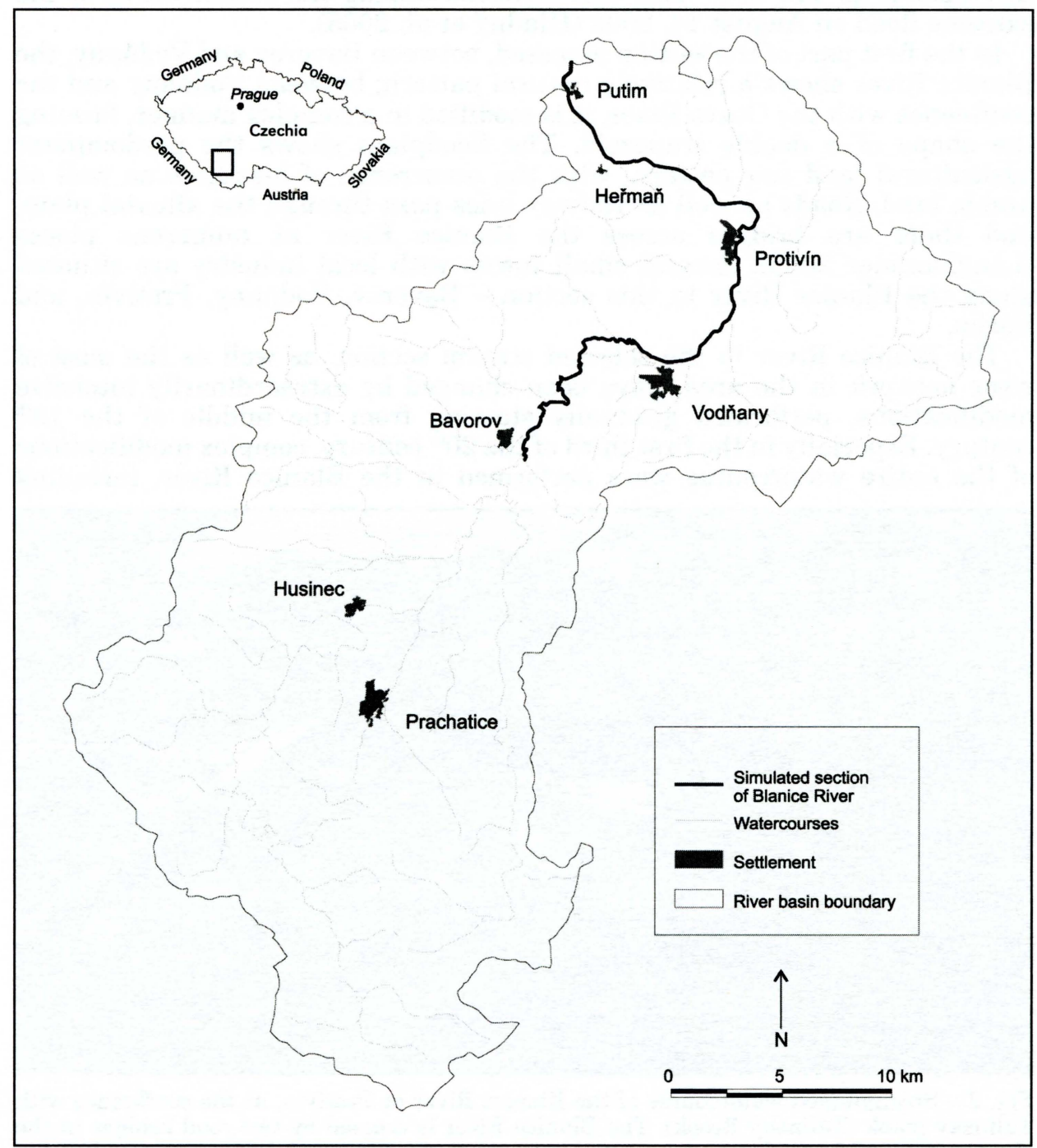

Fig. 1 - Blanice River with the simulated section of stream between Bavorov and the confluence with the Otava River highlighted 
reaches into the highest parts of Šumava in the Šumava National Park. The passage to the lowland part, in the area of Prachatice, is steep, and the watercourses achieve a high slope and energy in this area. The lowland part of the river basin on the lower watercourse of the Blanice River from Bavorov features a flat and wide alluvial plain. The plain width varies from 1-2 km in this area.

In the study, the section of the Blanice River and floodplain between Bavorov and the confluence with the Otava River is assessed. The length of this section is $40.5 \mathrm{~km}$; the average long-term flow of the Blanice River in the profile of Herrmaň before the mouth point amounts to $4.65 \mathrm{~m}^{3} \mathrm{~s}^{-1} ; \mathrm{Q} 2=47 \mathrm{~m}^{3} \mathrm{~s}^{-1}$; $\mathrm{Q} 100=300 \mathrm{~m}^{3} \mathrm{~s}^{-1}$. The highest flow recorded during the period observed corresponds to $443 \mathrm{~m}^{3} \mathrm{~s}^{-1}$ and was achieved during the second wave of the extreme flood on August 14, 2002 (Hladný et al. 2005).

In the first part of the section assessed, between Bavorov and Vodňany, the Blanice River shows a relatively natural pattern; between Vodňany and the confluence with the Otava River, it is modified in a complex manner, forming the shape of a double trapezoid. The floodplain shows the predominant agricultural land use pattern, with the occurrence of meadows as well as arable land. Roads as well as railway lines pass through the alluvial plain, and there are bridges across the Blanice River at numerous places (Langhammer 2003). Several small towns with local industry are situated along the Blanice River in this section - Bavorov, Vodňany, Protivín, and Putim.

The Blanice River in the selected stream section, as well as the most of river network in the area, have been changed by extraordinarily intensive modifications, performed gradually starting from the middle of the $19^{\text {th }}$ century. Especially in the first third of the $20^{\text {th }}$ century, complex modifications of the entire watercourse were performed in the Blanice River, including

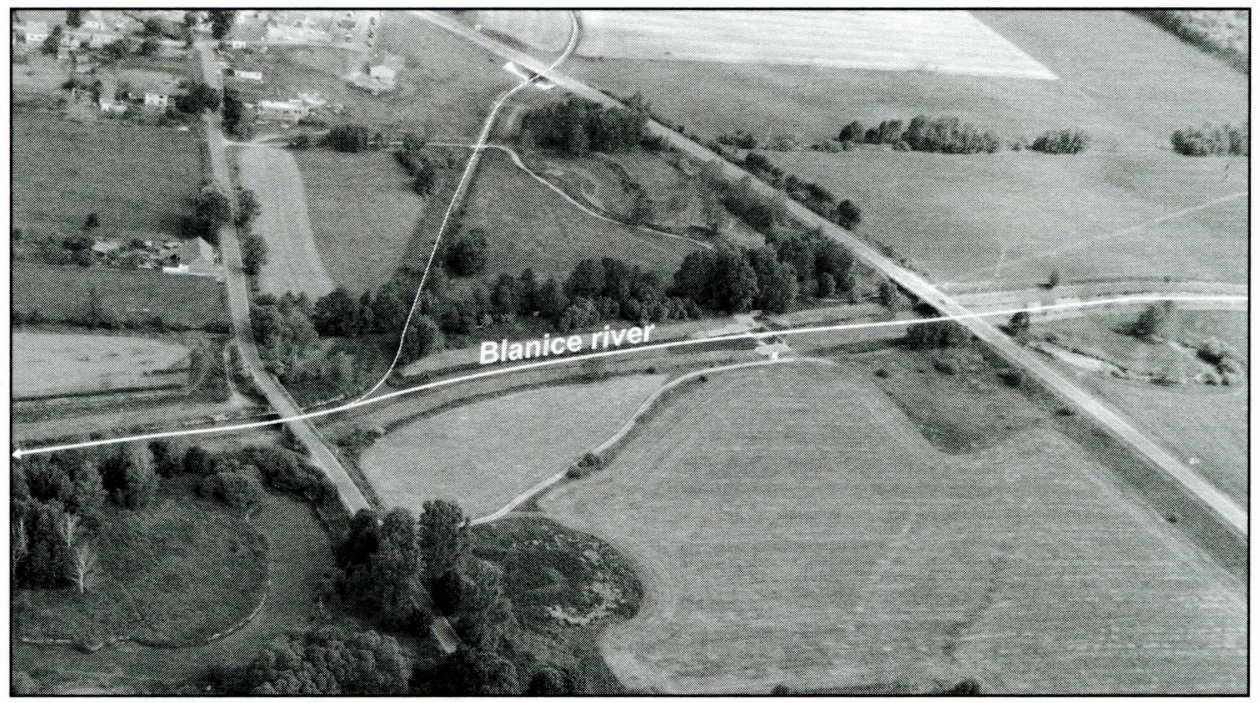

Fig. 2 - Straightened watercourse of the Blanice River at Protivín, at the confluence with Tálínský potok (Tálínský Brook). The Blanice River is crossed by two road bridges in the short section, and a high weir is situated between them. Remains of original meanders are apparent on the left bank, cut off upon straightening the watercourse bed. Photograph by Langhammer 2005 
straightening of the stream route, geometric modification of the riverbed, and the building of flood protection dikes in long and compact sections of the watercourse. These modifications prevent efficient usage of the retention and transformation potential offered by the wide and extensively used floodplain (Fig. 2).

\subsection{The Model and Its Application to the Blanice River}

The one-dimensional hydraulic model HEC-RAS was used to assess the impact of anthropogenic modifications of the Blanice River bed. This model currently represents one of standard tools used in research, as well as application practice, to calculate the flow dynamics in open channels and river beds.

The model HEC-RAS includes a 1D model of non-uniform flow in open beds, HEC2, and a 1D model of variable flow in river beds, UNET. The mathematical basis of the model stems from equations which describe the one-dimensional movement of water in the bed (HEC 2002a). The computational methods used make it possible to take into account flow obstructions, such as bridges, culverts and weirs (HEC 2002a, 2002b).

The model to simulate water flowing through the river bed stems from three groups of input data:

- Transverse profiles of the river bed and adjacent inundation zone

- River bed roughness coefficients

- Boundary conditions.

The definition of the stream channel model by a set of cross-sections was set up by the T.G.M. Water Research Institute in Prague (Havlík et al. 2003, Sitař 2007). The channel geometry was set up based on geodetically surveyed transverse profiles through the floodplain and the river bed, and a digital terrain model. Cross-sections were placed with irregular spacing in an interval of ca. 70-500 m, according to the nature of the floodplain relief and the watercourse bed. The transverse profiles ran across the entire inundation zone; the spacing was chosen in such a manner so that important elements of the plain morphology are captured. In places with rather complex flowing conditions and marked terrain changes, the profile intervals are shorter than $100 \mathrm{~m}$; in the case of uncomplicated sections, they may exceed $400 \mathrm{~m}$ (Fig. 3).

The model was calibrated for the flood situation of August 2002. The hydrogram of the flood second wave course from August 2002 was therefore used as a boundary condition; side tributaries and tributaries from the intermediate river basin were not taken into account.

\section{Results}

Four scenarios of river network changes were simulated. The basic simulation scenario represented the course of the flood in August 2002 on the original model. In the other scenarios of the model, the geometric parameters of the river bed and of the adjacent inundation zone were modified, and the simulation results were compared to the original model results. The following three scenarios of river network modifications were evaluated in regard to their impact on the course of the flood in August 2002:

- Impact of weirs on the flood course 
- impact of bridges and road embankments on the flood course

- impact of complex river bed modifications on the flood course.

\subsection{The Impact of Weirs on the Flood Course}

In the simulated segment of the Blanice River, the stream is marked by 17 weirs. The simulation results showed that their potential removal has a marginal impact on the flood course hydrograms. Comparison of the

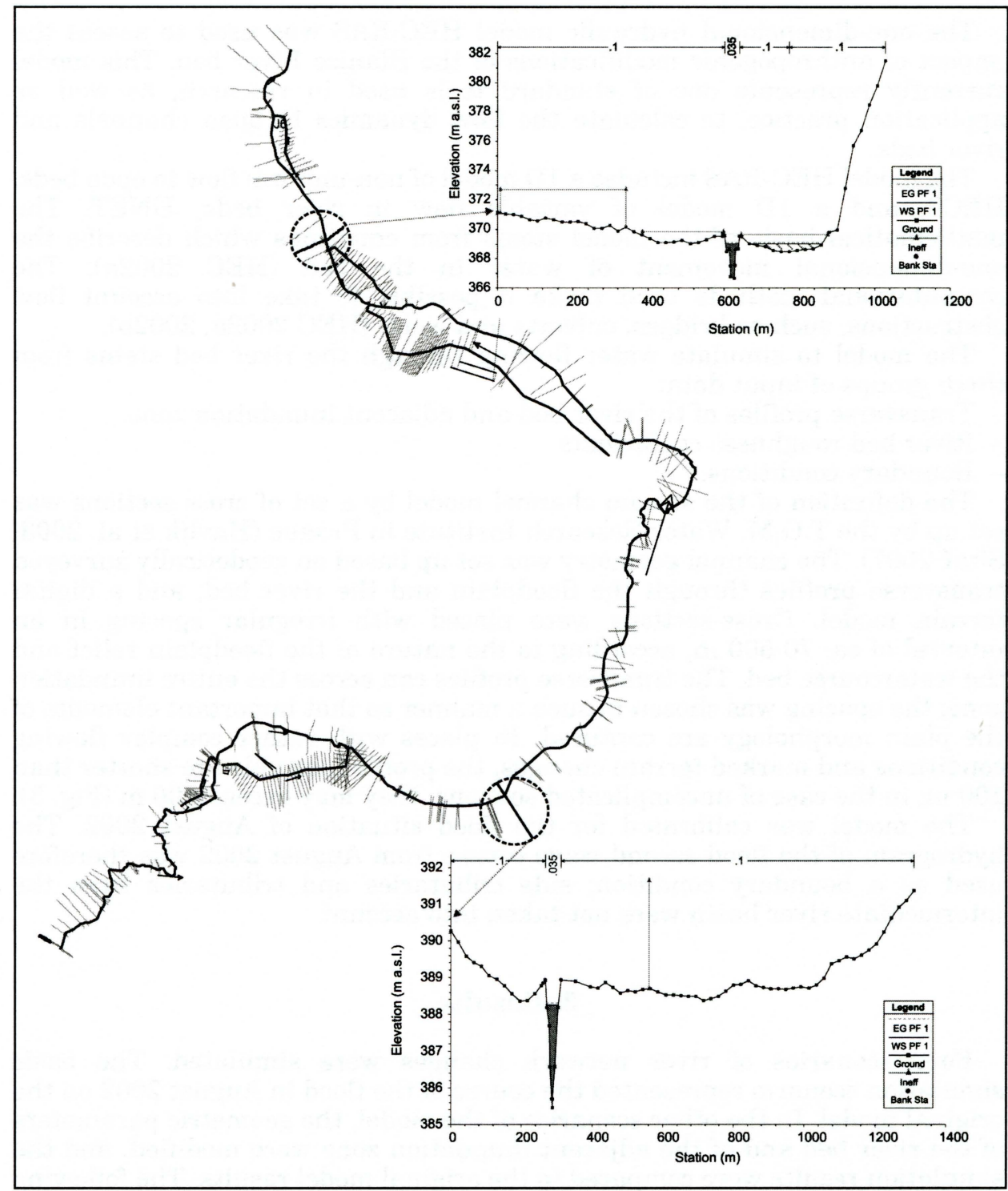

Fig. 3 - Scheme of the Blanice River channel representation in the HEC-RAS model. The scheme shows the frequency of cross-sections and the level of detail used for its construction. Data: VÚV T.G.M. 2002 
Tab. 1 - Comparison of the culmination time, flows, and water levels in selected profiles on the Blanice River using the model with and without weirs

\begin{tabular}{|l|c|c|c|c|c|}
\hline Profile & $\mathrm{Km}$ & Scenario & $\begin{array}{c}\text { Culmination } \\
\text { time }\end{array}$ & $\begin{array}{c}\text { Flow } \\
\left(\mathrm{m}^{3} \cdot \mathrm{s}^{-1}\right)\end{array}$ & $\begin{array}{c}\text { Water level } \\
(\mathrm{m} \text { above sea } \\
\text { level })\end{array}$ \\
\hline Bavorov & \multirow{2}{*}{36.165} & With weirs & $12.8 .12: 45$ & 476.23 & 419.43 \\
& & Without weirs & $12.8 .12: 45$ & 476.23 & 419.43 \\
Vodňany & 23.400 & With weirs & $12.8 .20: 16$ & 418.87 & 394.25 \\
& & Without weirs & $12.8 .20: 33$ & 417.06 & 394.24 \\
Protivín & \multirow{2}{*}{15.450} & With weirs & 13.8. 02:17 & 383.11 & 383.11 \\
& & Without weirs & $13.8 .02: 45$ & 380.75 & 383.10 \\
Her̆maň & \multirow{2}{*}{4.249} & With weirs & $13.8 .17: 08$ & 308.23 & 371.17 \\
& & Without weirs & $13.8 .17: 53$ & 307.02 & 371.16 \\
\hline
\end{tabular}

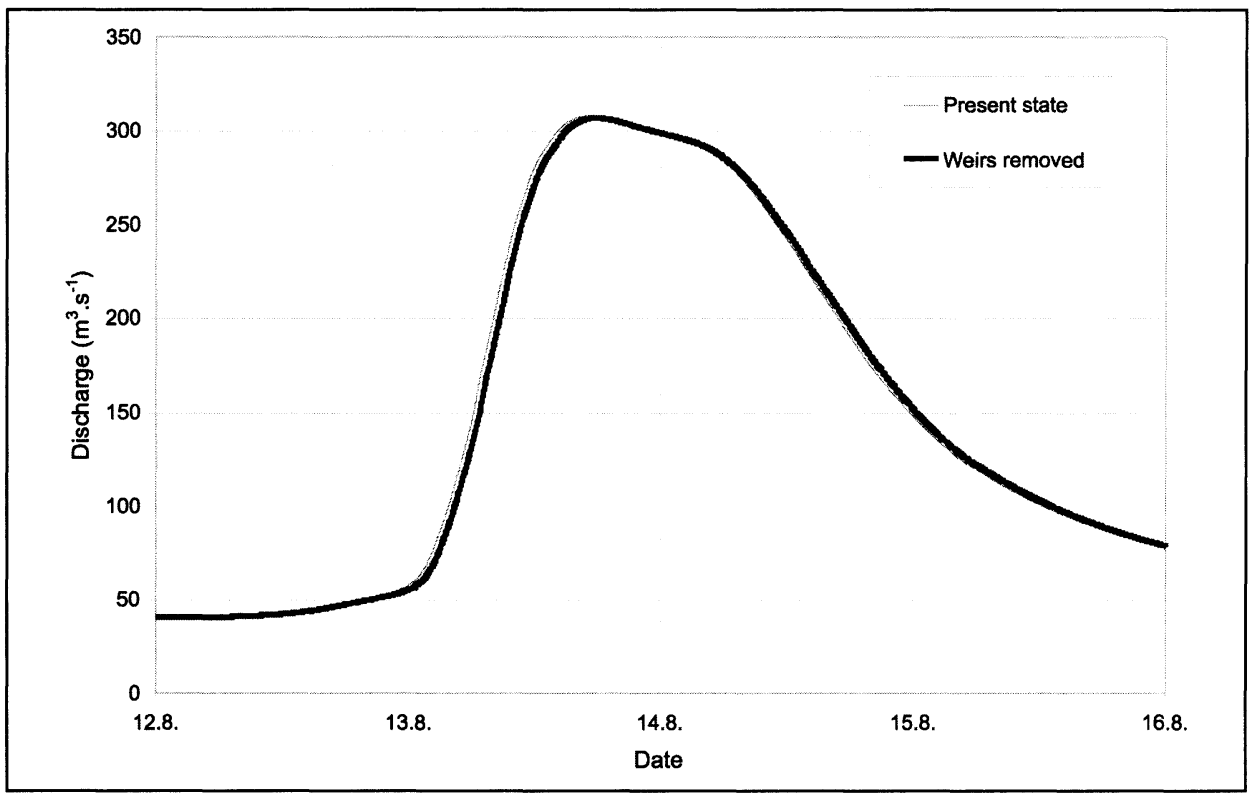

Fig. 4 - Comparison of the course of simulated hydrograms at the Heřmaň profile for the river bed with and without weirs

simulated culmination flows and water levels in Bavorov, Vodňany, Protivín, and Heřmaň is shown in Table 1 . In the case of the weir-free model, slightly lower peak flows and water levels were achieved in Vodňany, Protivín, and Heřmaň. The culmination flows differ by $1.81 \mathrm{~m}^{3} \cdot \mathrm{s}^{-1}$ in Vodňany, by $2.36 \mathrm{~m}^{3} \cdot \mathrm{s}^{-1}$ in Protivín, and by $1.21 \mathrm{~m}^{3} \cdot \mathrm{s}^{-1}$ in Heřmaň, representing a difference of $0.43,0.62$, and $0.39 \%$. The water levels achieved a level lower by only $1 \mathrm{~cm}$.

It follows from the comparison of the culmination times that the time difference of the peak flow time increases downstream. While in Vodñany, this difference is only 17 minutes, in Protivín it reaches 28 minutes, and reaches 45 minutes in Heřmaň. In the case of the model without weirs, partial transformation of the flood wave occurs; however, the differences and their importance for the overall course of the flood are minor. 
The impact of weirs on the flood wave shape in Heřmaň is shown in Figure 3. Upon removal of weirs from the river bed model, the culmination time of 5:53pm on August 13 was obtained, with the flow equal to $307.02 \mathrm{~m}^{3} \cdot \mathrm{s}^{-1}$ The maximum water level reached $371.16 \mathrm{~m}$ above sea level. Compared to the original model, in the case of the weir-free river bed the flood would have culminated 45 minutes later and the flow would have been lower by 1.21 $\mathrm{m}^{3} \cdot \mathrm{s}^{-1}$ (Table 1 ).

In lower water levels, water flowing in the river bed above the weirs slows down. The difference in speed can be observed almost in all weirs, while the differences achieve values up to $0.5 \mathrm{~m} . \mathrm{s}^{-1}$ (Fig. 4).

The maximum water levels reached are especially decisive for assessment of the flood consequences and of the damage caused as the water level in the culmination has a direct impact on the flooded area. In most profiles, water levels upon removal of the weirs differ only by several centimetres. In $56 \%$ of the profiles, culmination water levels of the model without weirs reach lower values (Tab. 2; Fig. 3). Of these, in $59 \%$ the water level was lower by only 1 $\mathrm{cm}$, representing almost $33 \%$ of the total number of profiles. In $22 \%$ of the profiles, there is no difference. Higher water levels were thus reached in the remaining $22 \%$ profiles. In $96 \%$ of the profiles, the difference of the water levels amounts to a maximum of $10 \mathrm{~cm}$.

\subsection{The Impact of Bridges on the Course of the Flood}

In second scenario, the bridges were removed from the Blanice River bed model. The course of simulated hydrograms at the Her̆man profile was compared to the situation corresponding to the actual state of the riverbed under conditions of the August 2002 flood. In the section observed, the model includes a total of 11 bridges. Upon removal of all bridges from the Blanice River bed model, peak flow at the Herrmaň station was reached at $3: 37 \mathrm{pm}$ on August 13, with the flow equal to $308.70 \mathrm{~m}^{3} \cdot \mathrm{s}^{-1}$ (Table 3). The maximum water level reached $371.17 \mathrm{~m}$ above sea level. Compared to the original model, the flood culminated 1 hour and 31 minutes earlier, representing an advancement time shortening by $5.3 \%$. The culmination flow was higher by $0.47 \mathrm{~m}^{3} \cdot \mathrm{s}^{-1}$ or by $0.15 \%$. The water level did not change and reached the same level, i.e., $371.17 \mathrm{~m}$ above sea level.

In Vodñany, the flood culminated at almost the same time as in the case of the original model, while further down along the watercourse a marked shift of the culmination time can be observed. In Protivín, the shift reached 1 hour and 6 minutes, and in Herrmañ the culmination time occurred 1 hour and 31 minutes earlier. In Vodňany and Protivín, the flow reached values higher by 2.78 and $14.44 \mathrm{~m}^{3} \cdot \mathrm{s}^{-1}$, respectively, a difference of 0.7 and $3.8 \%$, respectively. The water level did not differ in Vodňany, and in Protivín it was higher by $4 \mathrm{~cm}$. Comparison of the simulated hydrogram shapes in Heřmaň is shown in Fig. 4.

Furthermore, differences of simulated values of the watercourse flowing speeds and water levels in the original model and in the model without bridges were compared in individual profiles of the river bed model. At the beginning of the simulation, the simulated values did not differ; thus the bridges have no crucial impact on water flowing through the river bed when the water levels are lower. At culmination, the bridges do affect flowing of water. Upon removal of the bridges, water flows through the river bed slightly 
Tab. 2 - Comparison of the culmination time, flows, and water levels at selected profiles on the Blanice River with various modifications of the river bed geometry and of the inundation zone

\begin{tabular}{|c|c|c|c|c|c|}
\hline Profile & $\mathrm{Km}$ & Scenario & $\underset{\text { time }}{\text { Culmination }}$ & $\begin{array}{c}\text { Flow } \\
\left(\mathrm{m}^{3} \cdot \mathrm{s}^{-1}\right)\end{array}$ & $\begin{array}{c}\text { Water level } \\
\text { (m above sea } \\
\text { level) }\end{array}$ \\
\hline Bavorov & 36.165 & $\begin{array}{l}\text { Original model } \\
\text { Without bridges } \\
\text { Without bridges } \\
\text { and embankments }\end{array}$ & $\begin{array}{l}\text { 12.8. } 12: 45 \\
\text { 12.8. } 12: 45 \\
12.8 .12: 45\end{array}$ & $\begin{array}{l}476.23 \\
476.23 \\
476.23\end{array}$ & $\begin{array}{l}419.43 \\
419.43 \\
419.43\end{array}$ \\
\hline Vodňany & 23.400 & $\begin{array}{l}\text { Original model } \\
\text { Without bridges } \\
\text { Without bridges } \\
\text { and embankments }\end{array}$ & $\begin{array}{l}\text { 12.8. } 20: 16 \\
\text { 12.8. } 20: 18 \\
\text { 12.8. } 20: 18\end{array}$ & $\begin{array}{l}418.87 \\
421.65 \\
421.61\end{array}$ & $\begin{array}{l}394.25 \\
394.25 \\
394.23\end{array}$ \\
\hline Protivín & 15.450 & $\begin{array}{l}\text { Original model } \\
\text { Without bridges } \\
\text { Without bridges } \\
\text { and embankments }\end{array}$ & $\begin{array}{l}\text { 13.8. 02:17 } \\
\text { 13.8. 01:11 } \\
\text { 13.8. 00:35 }\end{array}$ & $\begin{array}{l}383.11 \\
397.55 \\
400.54\end{array}$ & $\begin{array}{l}383.11 \\
383: 15 \\
383.09\end{array}$ \\
\hline Heřmaň & 4.249 & $\begin{array}{l}\text { Original model } \\
\text { Without bridges } \\
\text { Without bridges } \\
\text { and embankments }\end{array}$ & $\begin{array}{l}\text { 13.8. } 17: 08 \\
\text { 13.8. } 15: 37 \\
\text { 13.8. } 14: 51\end{array}$ & $\begin{array}{l}308.23 \\
308.70 \\
310.92\end{array}$ & $\begin{array}{l}371.17 \\
371.17 \\
371.17\end{array}$ \\
\hline
\end{tabular}

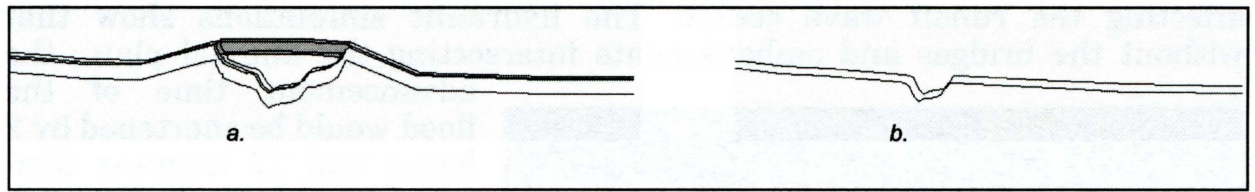

Fig. 5 - Scheme of modification of bridge and embankments in the simulated scenario before modification (a) and upon modification (b)

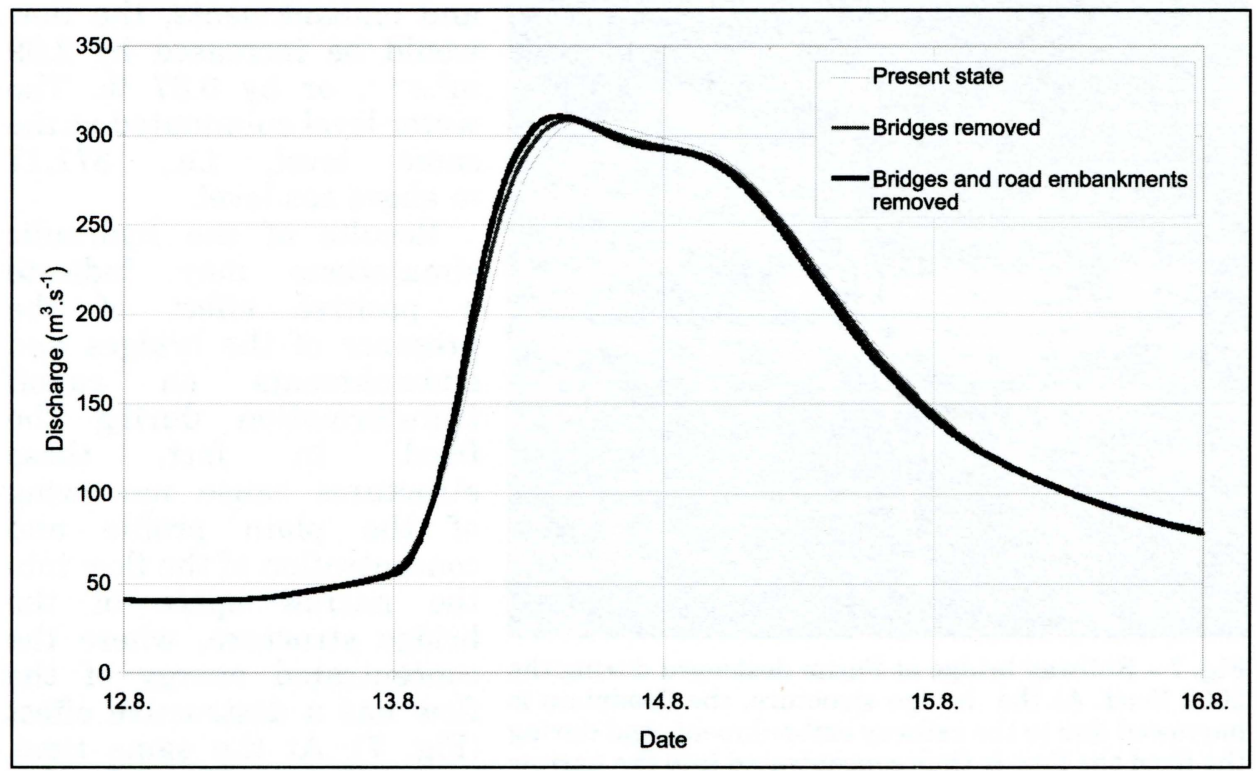

Fig. 6 - Comparison of the simulated hydrogram shapes at Heřmaň upon various modifications of the river bed geometry and of the inundation zone 
faster. The most marked difference can be observed above the bridge located at $\mathrm{km} 27.5$; upon removal of this bridge, water flowing would be faster by 0.91 $\mathrm{m} . \mathrm{s}^{-1}$. In other bridges, the differences are not as distinct and differ in the range of 0.1 to $0.2 \mathrm{~m} . \mathrm{s}^{-1}$. Together with accelerated water flow, the flow values increased as well. Maximum differences reached up to $14.5 \mathrm{~m}^{3} \cdot \mathrm{s}^{-1}$ in places.

In places where the bridges are found, the river bed shape and the adjacent inundation zone are often modified as well. In these places, the river bed is deepened, and road embankments are found in the inundation zone, representing obstructions to water flow.

A subscenario was tested to simulate the effect of removal of the bridges plus modification of the respective stream cross-sections by removing the road embankments while the terrain level of the floodplain and the riverbed was preserved (Figure 5).

By modifying the inundation zone geometry so that the road embankments would not form an obstruction to the flow, further acceleration of the flood advancement was achieved as expected, as well as an increase of the flow culmination values at selected profiles (Tab. 2). Culmination of the flood wave in Her̆maň thus occurred on August 13, 2002 at 2:51pm, with the flow equal to $310.92 \mathrm{~m}^{3} \cdot \mathrm{s}^{-1}$.

From comparison of the simulated hydrogram shapes at the Her̆maň profile (Fig. 6), it follows that the bridges and road embankments take part in affecting the runoff wave course. The hydraulic simulations show that without the bridges and embankments intersecting the alluvial plain, the

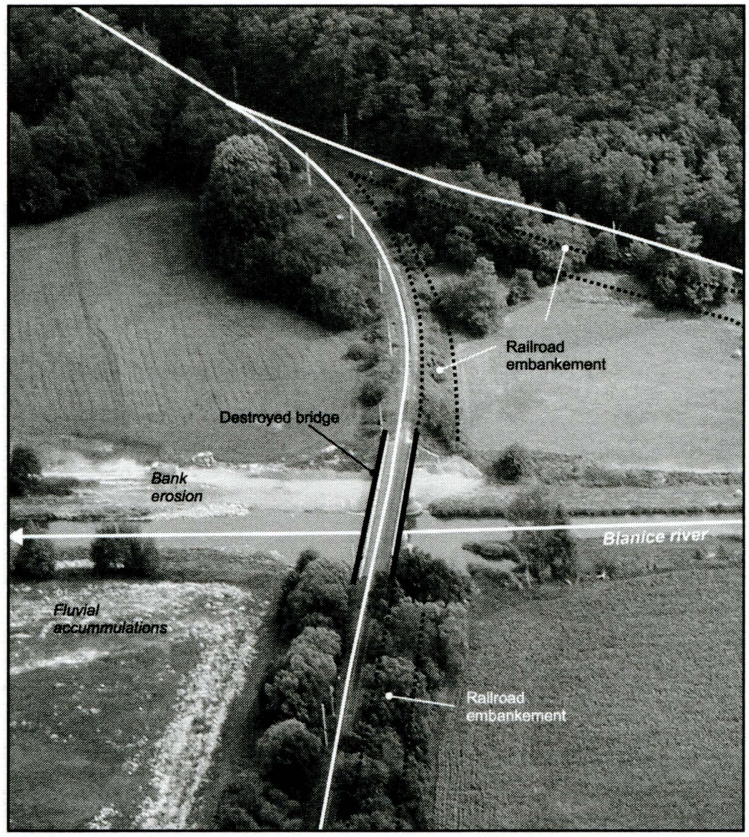

Fig. 7 - Railway bridge at Putim destroyed during the 2002 flood. At the bridge structure, the floodplain is narrowed due to the railway embankment, and during the flood the flow is thus concentrated into the narrow space of the bridge opening. Photograph by J. Langhammer, 2003 advancement time of the flood would be shortened by 2 hours and 17 minutes compared to the original model, i.e., approximately by $8 \%$. In the scenario without bridges and embankments, the flow would be increased by 2.69 $\mathrm{m}^{3} \cdot \mathrm{s}^{-1}$, or by $0.87 \%$. The water level culminated at the same level, i.e., 371.17 $\mathrm{m}$ above sea level.

Results of the hydraulic simulations may indicate a positive effect of the presence of the bridges and embankments on runoff transformation during the flood. In fact, these structures cause narrowing of the plain profile and concentration of the flow into the narrow space of the bridge structure, where the concentrated energy of the flow has a destructive effect (Fig. 7). At the same time, locations of narrowed flowing often tend to become blocked 
Tab. 3 - Comparison of the culmination times and flow values and water levels achieved in the case of the original model and the model with modified transversal profiles at selected profiles of the Blanice River

\begin{tabular}{|l|c|c|c|c|c|}
\hline Profile & $\mathrm{Km}$ & Scenario & $\begin{array}{c}\text { Culmination } \\
\text { time }\end{array}$ & $\begin{array}{c}\text { Flow } \\
\left(\mathrm{m}^{3} . \mathrm{s}^{-1}\right)\end{array}$ & $\begin{array}{c}\text { Water level } \\
(\mathrm{m} \text { above sea } \\
\text { level })\end{array}$ \\
\hline Bavorov & \multirow{2}{*}{36.165} & Original & $12.8 .12: 45$ & 476.23 & 419.43 \\
& & Without dikes & $12.8 .12: 45$ & 476.23 & 419.43 \\
Vodňany & 23.400 & Original & $12.8 .20: 18$ & 418.76 & 394.25 \\
& & Without dikes & $12.8 .20: 33$ & 417.06 & 394.24 \\
Protivín & \multirow{2}{*}{15.450} & Original & $13.8 .02: 42$ & 377.07 & 383.10 \\
& & Without dikes & $13.8 .02: 45$ & 380.75 & 383.10 \\
Heřmaň & \multirow{2}{*}{4.249} & Original & $13.8 .17: 08$ & 308.23 & 371.17 \\
& & Without dikes & $13.8 .17: 46$ & 306.62 & 371.02 \\
\hline
\end{tabular}



Fig. 8 - Cross-section of the innundation zone at $\mathrm{km} 8.385$ before modification of the profile (a) and after modification (b)

by materials carried by the flood, causing subsequent acceleration of erosion processes in the surroundings of the artificial obstruction, and upon its rupture, a massive accumulation of the carried materials occurs, and a secondary flood wave is often caused.

\subsection{The Impact of Complex River Bed} Modifications on the Course of the Flood

In the lower part of the Blanice River, from Vodňany to its confluence with the Otava River, a complex modification of the river bed can be seen. In this section, the river bed shows a trapezoidal shape with flood protection dikes on the banks. The modification was performed in the 1920s when the Blanice River was straightened considerably. This is a marked anthropogenic intervention in the river bed shape, leading to its increased capacity. The modification should be dimensioned for design flow of up to $90 \mathrm{~m}^{3} \cdot \mathrm{s}^{-1}$ (Šobr 2005).

For this simulation scenario, the cross-sections of the river bed and inundation zone were modified so the elevations representing the dikes were removed from both banks of the river bed (Fig. 8).

The simulation results were compared again to the values achieved in the original model (Table 3). Upon modification of the shapes of transversal profiles, the flood culminated at Heřmaň at 5:46 pm, with a flow equal to $306.62 \mathrm{~m}^{3} \cdot \mathrm{s}^{-1}$ and with a water level of $371.02 \mathrm{~m}$ above sea level. The advancement time of the flood was extended by 38 minutes, the peak flow was reduced by $1.61 \mathrm{~m}^{3} \cdot \mathrm{s}^{-1}$, and the water level was reduced by $15 \mathrm{~cm}$.

Upon removal of barriers from the river channel, flows and water levels decreased at the beginning of the simulation at most of the assessed profiles. The decrease of peak discharge was $0.78 \mathrm{~m}^{3} \cdot \mathrm{s}^{-1}$ at the maximum (Fig. 9); the water level differences varied from 1 to $22 \mathrm{~cm}$.

By means of modifying the river bed and the inundation zone geometry, flow conditions changed. This was manifested in decelerated advancement of 


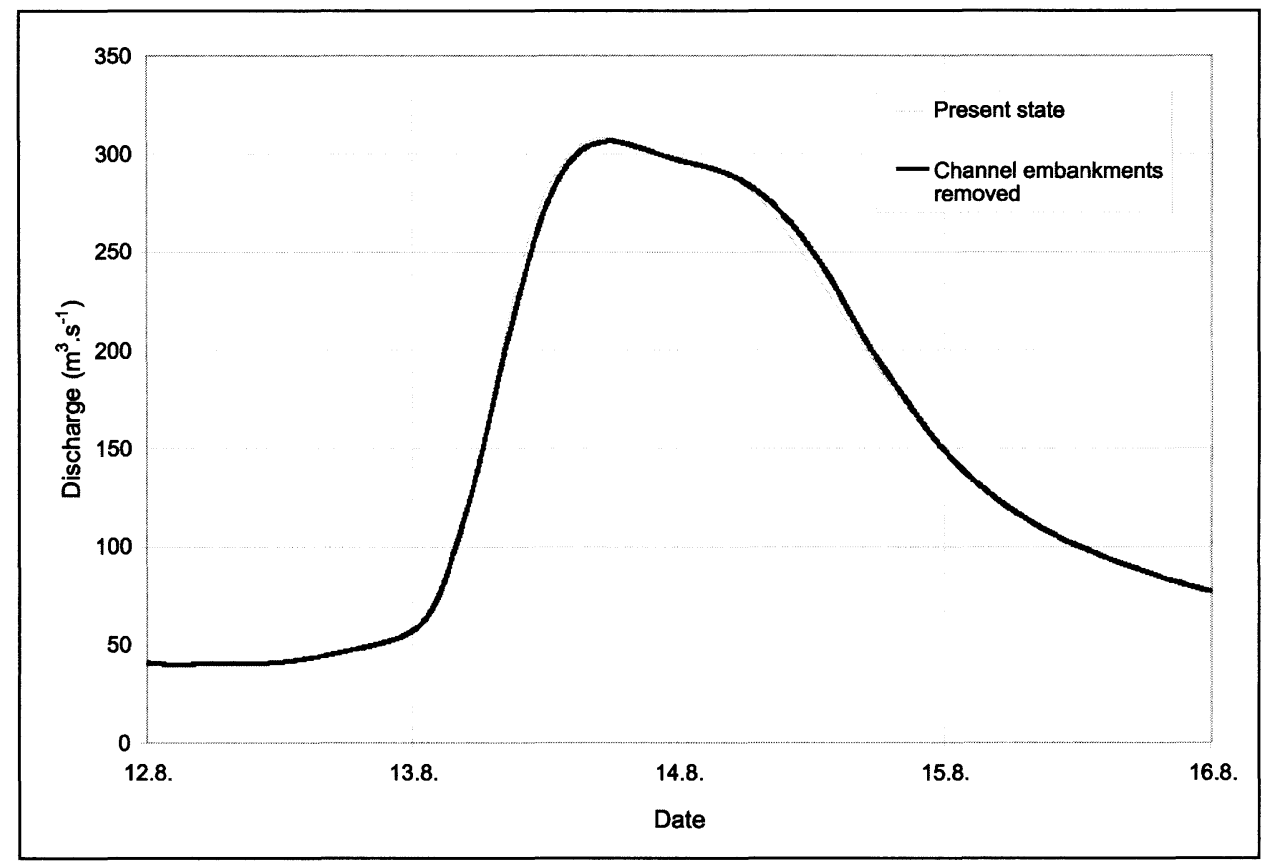

Fig. 9 - Comparison of the simulated hydrogram shapes at Heřmaň in the case of the original model and the model with the modified transversal profile shape

the flood and in a decrease of culmination water levels in most of the modified profiles.

\section{Discussion and Conclusions}

Results of the model helped to quantify the outcomes and assumptions of preceding studies dealing with the impact of river bed modifications on the course of floods in extreme events (Bryant, Gilvear 1999; Havlík 2002; De Roo et al. 2001 ). Scenario-based modelling of the course of the 2002 flood in the Blanice River confirmed that in extreme events, the impact of modifications which affect the river bed roughness and flow conditions was minimum, and that such modifications of the watercourse and riparian zone had no essential impact on the time course and the flood wave transformation (Langhammer, Vilímek 2007).

On the contrary, an important role is played by modifications acting as potential flow obstructions, which include bridges and road embankments crossing the inundation zone (Havlík et al. 2002). The impact of unsuitably localised or insufficiently dimensioned constructions of bridges and culverts leads to local increases of the flow dynamics, and moreover, extreme manifestations of destruction can be seen regularly in such localities, as well as erosion and accumulation of materials carried by the flood.

Out of the river bed modifications and floodplain modifications assessed, the effect of complex river bed modifications were the most important; however, overall results in all scenarios show that the impact of the modifications assessed on the course of the 2002 flood was negligible. 
Simulations of the impact of weirs on flow during the flood showed that under extreme runoff conditions when maximum water level is up to several metres higher than normal values, the effect of weirs on the flow dynamics is minimal. The impact of theoretical removal of the weirs on the achieved peak flows is marginal - the decrease of peak flow reaches slightly less than one per cent of the flow, while the flood duration time can be extended by up to 45 minutes.

However, the impact of weirs on the course and consequences of the flood consists especially of affecting the dynamics of fluviomorphological processes in which the weirs act as centres of intensive erosion, accumulation, and destruction in the river bed and in the floodplain (Křížek, Engel 2004). However, hydraulic models cannot capture these aspects of the flood activity.

Simulations of the effect of bridges and road embankments intersecting the floodplain had similar outcomes. The model results indicated the seemingly positive effect of these constructions on the runoff transformation. Upon their removal, the flood advancement was accelerated by more than 2 hours, and observable lowering of the water level occurred. This result should be interpreted in relation to the fluvial processes occurring in the riverbed and floodplain during the floods. Deceleration of flow beyond the embankment and bridge bodies does not represent a positive effect which could be indicated by mechanistic interpretation of model results. It is rather the opposite, as in floods these objects represent one of the most critical elements of the river network (Langhammer 2003). Construction of bridges and culverts causes temporary blockage by materials carried by the flood and formation of temporary flow barriers. Upon their rupture, the bridge or culvert structure is usually damaged, and extensive erosion and accumulation occurs in the immediate surroundings. Moreover, a sharp increase of the flow upon destruction of these artificial obstructions can complicate the course of the flood within the lower sections of the watercourse.

The most valuable results from the viewpoint of their practical applicability were the simulation of complex river bed modifications, including the impact of flood protection dikes. The issue of the impact of intensive watercourse modifications on the extremity of extraordinary floods was intensively discussed in connection with extreme floods in 1997 in Moravia and in 2002 in Bohemia, and has also been systematically studied in different geographical regions (Langhammer, Vilímek 2007). The findings based on the modelling results in the Blanice River confirm the general assumptions formulated in the different physiogeographical conditions.

The impact of complex modifications of the river bed on the flood course is of crucial importance. However, under extraordinary levels of flood magnitude, as was the case of the August 2002 flood, these modifications did not have essential impact on the course and magnitude of the entire event. Extension of the flood duration time upon removal of the barriers amounts to 38 minutes, which represents a change of $2.2 \%$. Reduction of the culmination flow amounts to $0.52 \%$ of the maximum value achieved; the water level decreased by $15 \mathrm{~cm}$, corresponding to $3.2 \%$; and the overall range of the flood decreased by $4.4 \%$.

The reason for such small impacts of individual river beds and floodplain modification types and their simulated removal on transformation of the flood wave in 2002 can be seen in unprecedented extremity of the flood event. In the situation when the entire area of the floodplain is engaged in the runoff, and when even overflowing of the flood protection barriers occurs, 
watercourse modifications assessed have only marginal influence on the flow dynamics within the inundation zone. However, the effects of such types of river bed modifications will be substantially higher in cases of events with a lower magnitude.

Moreover, the study also indicated also the limits of a purely hydraulic assessment of the flood course. Modifications of the river bed, which from hydrodynamic viewpoint have a positive impact on transformation of the runoff, represent in fact a source of a considerable risk. Detailed analyses of the consequences of recent extreme flood events pointed out this fact (Langhammer, Vilímek 2007; Sear, Newson 2003; Vilímek, Kalvoda 1998). However, these processes cannot be assessed using hydrodynamic models, which can simulate only water movement in an open channel. In order to interpret the results, it is always necessary to take into account the complex nature of the processes taking place within the floodplain during the flood.

\section{References:}

BATES, P. D., DE ROO, A. (2000): A simple raster-based model for flood inundation simulation. Journal of Hydrology(Amsterdam), 236, 1, pp. 54-77.

BEFFA, C., CONNELL, R. J. (2001): Two-dimensional flood plain flow. I: Model description. Journal of Hydrologic Engineering, 6, No. 5, pp. 397-405.

BRYANT R. G., GILVEAR, D. (1999): Quantifying geomorphic and riparian land cover changes either side of a large flood event using airborne remote sensing: River Tay, Scotland. Geomorphology, 29, No. 3-4, pp. 307-321.

DE ROO, A., ODIJK, M., SCHMUCK, G., KOSTER, E., LUCIEER, A. (2001): Assessing the effects of land use changes on floods in the meuse and oder catchment. Physics and Chemistry of the Earth, Part B: Hydrology, Oceans and Atmosphere, 26, No. 7-8, pp. 593-599.

GILVEAR, D. (1999): Fluvial geomorphology and river engineering: future roles utilizing a fluvial hydrosystems framework. Geomorphology, 31, No. 1-4, pp. 229-245.

HAVLÍK, A. a kol. (2002): Matematické modelování šírení povodňových vln v povodí Divoké a Tiché Orlice. In: Sborník příspěvků Workshopu 2002 Extrémní hydrologické jevy v povodích. CVUT, Praha, pp. 79-84.

HAVLÍK, A. a kol. (2003): Transformace povodňových vln ze srpna 2002 na Berounce a Blanici. Dílčí část projektu Vyhodnocení katastrofální povodně v srpnu 2002. VÚV TGM, Praha, 33 p.

HEC (2002a): HEC-RAS River Analysis System Hydraulic Reference Manual. U.S. Army Corps of Engineers, <http://www.hec.usace.army.mil/software/hec-ras/hecrasdocument.html $>$ (10.8.2007).

HEC (2002b): HEC-RAS River Analysis System Users Manual. U.S. Army Corps of Engineers, <http://www.hec.usace.army.mil/software/hec-ras/hecras-document.html> (10.8.2007).

HORRITT, M. S., BATES, P. D. (2002): Evaluation of $1 \mathrm{D}$ and 2D numerical models for predicting river flood inundation. Journal of Hydrology, 268, No. 1-4, pp. 87-99.

KALVODA, J., VILÍMEK V. (1998): Metodika hodnocení geomorfologických změn v údolích po extrémních srážkách a povodni na Moravě v roce 1997, PřF UK, Praha.

HARTVICH, F., LANGHAMMER, J., VILÍMEK, V. (2007): The 2002 flood consequences in the catchment of Otava River, Czech Republic. Water Resources, 34, No. 1, pp. 14-26.

HLADNÝ, J., KRÁTKÁ, M., KAŠPÁREK, L. (2005): August 2002 - Catastrophic flood in the Czech republic, Water Research Institute TGM, Prague, 48 pp.

LANGHAMMER, J. (2003): Anthropogenic Transformation of River Network in the Otava River Basin. Acta Universitatis Carolinae-Geographica, 38, No. 2, pp. 139-156.

LANGHAMMER, J. (2006): Identification of critical elements in river network in regard to the flood risk. Acta Universitatis Carolinae-Geographica, 41, 1-2, p. 151-168.

LANGHAMMER, J., VAJSKEBR, V. (2003): Historical Shortening of River Network in the Otava River Basin. Acta Universitatis Carolinae-Geographica, 38, No. 2, pp. 109-124.

LANGHAMMER, J., VILÍMEK, V. (2007): Landscape changes as a factor affecting the 
course and consequences of extreme floods in the Otava river basin, Czech Republic. Environmental Monitoring and Assessment, DOI 10.1007/s10661-0.

SEAR, D. A., NEWSON, M. D. (2003): Environmental change in river channels: a neglected element. Towards geomorphological typologies, standards and monitoring. The Science of The Total Environment, 310, No. 1-3, pp. 17-23.

SITAŘ, J. (2007): Modelování vlivu antropogenních úprav jihočeské Blanice na průběh povodní. Diplomová práce. PřF UK, Praha. $136 \mathrm{~s}$.

VERWEY, A. (2001): Latest Developments in Floodplain Modelling-1D/2D Integration.

YIN, LI (2001): Human impact on floods and flood disasters on the Yangtze River. Geomorphology, 41, No. 2-3, pp. 105-109.

ŠOBR, M. (2005): Protipovodňová opatření v povodí Blanice. In: Langhammer J (eds.): Vliv změn prírodního prostředí povodí a údolní nivy na povodňové riziko. PřF UK, Praha, pp. $162-165$.

\section{Shrnutí}

\section{MODELOVÁNÍ VLIVU ANTROPOGENNÍCH ÚPRAV KORYTA TOKU NA PROUDĚNÍ PŘI EXTRÉMNÍ POVODNI}

Příspěvek ukazuje možnosti hodnocení vlivu antropogenních úprav koryta a inundačního území na prủběh povodní pomocí metod hydraulického modelování. Antropogenními zásahy do koryt toků mohou v závislosti na podmínkách prostředí a extremity povodně významně ovlivňovat průběh a následky povodní v lokálním měřítku i v měřítku povodí jako celku. Mezi úpravy, které mohou nejvýrazněji ovlivnit průchod povodňové vlny inundačním územím patř́i změny vedení trasy koryta, úpravy podélného profilu toku, změny př́čných profilů a změny $\mathrm{v}$ charakteru využití území údolní nivy a příbřežní zóny. Vhodný nástroj pro podrobnou kvantitativní analýzu dynamiky proudění v korytě a inundační zóně a její změny v důsledku úprav říční sítě představují v současné době hydraulické modely, propojené s GIS.

Studie představuje výsledky analýzy vlivu základních typů vodohospodářských úprav koryt toků na průběh extrémní povodně, zpracované pomocí matematického hydraulického modelu. $\mathrm{Z}$ typů úprav je zkoumán vliv jezů, mostů, náspů vedených např́č údolní nivou a povodňových hrází.

V příspěvku je použit použit hydraulický jednorozměrný model pro simulaci proudění vody $\mathrm{v}$ otevřených korytech HEC-RAS. Otázka vlivu antropogenních změn koryta toku na průběh povodně je hodnocena na příkladu povodí jihočeské Blanice pro situaci odpovídající extrémní povodni ze srpna 2002.

Výsledky simulací potvrdily předpoklad, že antropogenní úpravy koryt vodních toků a př̀lehlého inundačního území ovlivňují celkový průběh extrémních povodní jen minimálně. Na průběh povodně mají na lokální úrovni negativní vliv jezy a nevhodně dimenzované mosty, simulace rovněž prokázaly negativní vliv rozsáhlých komplexních úprav koryta, které byly provedeny na dolním toku Blanice v 1 . polovině 20 . století, celkový vliv na průtok či vodní stav při kulminaci a na dobu doběhu povodně je zanedbatelný.

Výsledky navíc ukazují i na limity ve využití výsledků hydraulického modelování pro hodnocení povodnňového rizika. Některé typy úpravy koryta, jmenovitě jezy totiž z čistě hydrodynamického pohledu indikují pozitivní vliv na transformaci odtoku, při povodňové situaci však naopak představují výrazný zdroj rizika vzhledem $\mathrm{k}$ akceleraci fluviálně morfologických procesů v korytě toku a údolní nivě. Tyto procesy však běžnými hydrodynamickými modely, které se soustředí pouze na simulaci pohybu vody v otevřeném korytě, není možné simulovat. Intepretaci výsledků modelování je zapotřebí vždy provádět $\mathrm{v}$ kontextu komplexního charakteru rizikových procesů, probíhajících v údolní nivě při povodni.

Obr. 1 - Modelovaný úsek toku Blanice mezi Bavorovem a soutokem s Otavou.

Obr. 2 - Napřímený tok Blanice u Protivína $\mathrm{v}$ místě soutoku $\mathrm{s}$ Tálínským potokem. Tok Blanice protínají na krátkém úseku dva silniční mosty, mezi kterými je situován vysoký jez. Na levém břehu jsou zřejmé pozůstatky původních meandrů, odříznutých při napřímení koryta toku. Foto Langhammer 2005.

Obr. 3 - Ukázka definice korytového modelu Blanice v modelu HEC-RAS. Schéma zobrazuje proměnlivou četnost př́čných profilů a jejich podrobnost. Data: VÚV T.G.M. 2002 . 
Obr. 4 -Srovnání průběhu simulovaných hydrogramů v profilu Heřmaň v případě koryta $\mathrm{s}$ jezy a bez jezů.

Obr. 5 - Schéma úpravy mostu a hrází ve varianě modelu před úpravou profilu (a) a po úpravě (b).

Obr. 6 - Srovnání tvaru simulovaných hydrogramů v Heřmani při různých úpravách geometrie koryta a inundačního území.

Obr. 7 - Želeniční most u Putimi, stržený při povodni 2002. V místě mostní konstrukce je díky náspu železnice zúžená niva a proud při povodni je tak koncentrován do úzkého prostoru mostního otvoru. Foto Langhammer 2003.

Obr. 8 - Profil 8,385 před úpravou (a) a po úpravě (b).

Obr. 9 - Srovnání tvaru simulovaných hydrogramů v Heřmani v případě původního modelu a modelu s upraveným tvarem prŕíčných profilů.

Authors are with Charles University in Prague, Faculty of Science, Department of Physical Geography and Geoecology, Albertov 6, 128 43, Praha 2, Czechia;

e-mail: langhamr@natur.cuni.cz; sitar@natur.cuni.cz.

Arrived to the editorial board on April 2, 2008 